\title{
70. 不娠患者に対する腹腔鏡検查の検討
}

\author{
（大阪大学医学部産婦人科学教室） \\ 亀田隆 -上浦祥司・鮫島義弘 \\ 大橋一友・松崎乐・東 千 尋 \\ 根 来 孝夫・佐 治文隆・谷澤修
}

〈諸言〉 不妊症患者に腹腔鏡が行われる様に なりそそれで不明であった異常所見が明らかに なると共に，従来行われてきた卵管通過性検査に 不十分な点の多い事がわかってきた. 我々は55名 の不妊症患者に施行した腹腔鏡検查成績について 報告すると共に, 原因不明不妊及び卵管通過性検 査について検討を行った.

<対象> 当科不妊外来通院中で, 昭和 60 年 10 月より昭和 62 年 5 月までに腹腔鏡を施行した 55 名の不妊患者を対象とした。平均年令 32 才, 平均不妊期間 6 年, 原発性不妊 45 名, 続発 性 不 妊 10 名であった。

〈方法> 腹腔鏡の麻酔は全例挿管による全身 麻酔を行った。気腹には炭酸ガスを使用し, 卵管 通過性の診断は生食で約 10 倍希釈したインジゴ カルミンを用いた。 また症例に応じ，種々の鉗子 類を用いた癒着䟝離, 生食約 $100 \mathrm{ml}$ による通水術 を行った。通気検査は炭酸ガスを用い，子宮卵管 造影は水溶性造影剤であるエンドグラフィンを使 用した。

〈結果> 55 名のうち 45 名 (82\%) に何らかの 異常所見が腹腔鏡によって認められた。最も多か ったのは子宮内膜症及び 卵管の異常(卵管周囲癒 着も含めた卵管閉塞や卵管水腫)で, 各々 19 名 (35\%)であった。 また腹腔鏡によっても不妊原因 のわからない例が 10 名(18\%)に認められた。腹 腔鏡施行前に 不妊原因が不明であった例は 24 名 であったが，このうち 15 名(62\%)は腹腔鏡によ り何らかの異常所見が認められた。15 名のうち子
宮内膜症が 8 名, 卵管の異常が 7 名であった. 次 に卵管通過性に関して通気検查, 子宮卵管造影々 腹腔鏡下通水検査との比較検討を行った。 その結 果通気検査, 子宮卵管造影共に 約 $60 \%$ が腹腔鏡 所見と診断が一致した。しかし卵管通過性がある と誤って診断されていた例が通気検査で $44 \%$, 子 宮卵管造影で $23 \%$ に認められた。逆に卵管通過 性がないと誤って診断されていた例が通気検査で $34 \%$ ，子宮卵管造影で $43 \%$ に認められた。 また この腹腔鏡検査後に 7 名が妊娠した. このうち 4 例は卵管周囲癒着䟝離術により 卵管可動性及び通 過性の明らかな改善を認めた。 また他の 3 例は生 食による通水術を施行していた。

〈考察〉腹腔鏡は不妊㭘査及び 癒着䟝離など の治療に極めて有用である。また今回の検討によ り通気検査や子宮卵管造影などの卵管通過性検査 の特性についても明らかとなった。つまり通気検 査に打いてはその所見にかかわらず約 $40 \%$ で腹腔 鏡との不一致が認められた。一方子宮卵管造影で

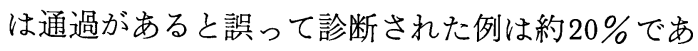
った，通気検查や子宮卵管造影の判定が一方は描 記曲線や通気音などの間接所見によるのに対し他 方はX線での直接所見による差が関連すると考え られる。また腹腔鏡施行前に不妊原因が不明と考 えられていた例の約 $60 \%$ に腹腔鏡で異常を認め た.このことは先の卵管通過性検査結果とも合わ せて腹腔鏡検査が不妊検査・治療上さわめて有用 であることを示す。 